\title{
Erratum to: Superstructure-based synthesis and optimisation of an oil palm eco-industrial town: a case study in Iskandar Malaysia
}

\author{
Mohamad Firdza Mohamad Shukery ${ }^{1,2,3} \cdot$ Haslenda-Hashim $^{1} \cdot$ Jeng Shiun Lim $^{1}$
}

Published online: 24 September 2016

(c) Springer-Verlag Berlin Heidelberg 2016

\section{Erratum to: Clean Techn Environ Policy DOI 10.1007/s10098-016-1220-1}

In the original publication of the article, the Grant of Vot. Q.J130000.2709.01K08 has been incorrectly published in the Acknowledgement section. The correct one is Grant of Vot. R.J130000.7809.4F618.

The online version of the original article can be found under doi:10.1007/s10098-016-1220-1.

Haslenda-Hashim

haslenda@utm.my

1 Process Systems Engineering Center (PROSPECT), Research Institute of Sustainability Environment (RISE), Universiti Teknologi Malaysia, Johor, Malaysia

2 Faculty of Chemical and Energy Engineering, Universiti Teknologi Malaysia, Johor, Malaysia

3 Department of Biological and Agricultural Engineering, Faculty of Engineering, Universiti Putra Malaysia, Selangor, Malaysia 